\title{
Two cases of angular pregnancy with incomplete abortion treated with hysteroscopy: a case report and review of literature
}

\author{
Yin Meichen, Fei Jing, Zhai Lingyun and Zhou Jianwei
}

\begin{abstract}
Background: Angular pregnancy is characterized as implant medial to the uterotubal junction in lateral angular of uterine. It was a rare obstetric complication with severe complications like uterine rupture and retained placenta.

Case presentation: We report a case of 2 incomplete aborted angular pregnancy that was diagnosed and treated with hysteroscopy. In this case, both of patient were performed operative hysteroscopy for incomplete abortion, and with the assistance of hysteroscopy, the angular pregnancy was detected.

Conclusions: Hysteroscopy can more intuitively display the conditions inside the uterine cavity, reduce the intraoperative and postoperative complications, and shorten the hospitalization time of patients. During hysteroscopy, angular pregnancy can be visualized in the upper lateral side of the uterine cavity. Based on the investigation results of clinical cases, this is the first case report of hysteroscopy in the treatment of incomplete aborted angular pregnancy.
\end{abstract}

Keywords: Angular pregnancy, Hysteroscopy, Incomplete abortion

\section{Background}

Angular pregnancy occurs in the following conditions that embryo implants medial to the uterotubal junction and round ligament, while mainly located in the endometrium of the lateral angle of uterus. It was a rare obstetric complication which is first described by the American obstetrician Howard Kelly in 1898 [1]. Unlike interstitial pregnancy, the embryo may develop or miscarry in the uterine cavity. And there are possibilities that angular pregnancy can progress to term. In contrast to normal pregnancy, the placenta in angular pregnancy grows on the restricted, fairly sharp edges of the uterine angle lead to abnormal adhesion of placenta, thickened placenta

\footnotetext{
*Correspondence: 2195045@zju.edu.cn
}

Department of Gynecology, The Second Affiliated Hospital of Zhejiang University School of Medicine, No88, Jiefang Road, Shangcheng District, Hangzhou 310002, Zhejiang, People's Republic of China and muscle weakness. Several life-threatening complications have been reported, including uterine rupture in placenta percreta, retained placenta during vaginal delivery, and hysterectomy due to placenta accreta. In addition to this, taking anatomical factors of uterine angle into consideration, we speculated the increased risk of pregnancy-related complications, including placental abruption, preterm delivery, postpartum endometritis, and growth restriction [2-4]. A meta-analysis supports the view that hysteroscopic resection of products led to a complete removal of products with a lower rate of abnormal complications and intrauterine adhesions compared to blind curettage [5].

A peculiar aspect of these two cases is that we have utilized operative hysteroscopy to remove the incomplete gestational sac located in angular uterine cavity safely and effectively. We present the following cases following the Case REpor (CARE) guidelines. 


\section{Case presentation}

Case 1

A 34-year-old woman, gravida 3 para 1 at 7 weeks, presented to our hospital for incomplete miscarriage. On April 2, 2018, the patient, diagnosed with early pregnancy, accepted abortion guided with hysteroscopy at Taizhou Boai hospital. However, on the 1 week after surgery, the patient was readmitted to the local hospital due to persistent and massive vaginal bleeding. And Blood HCG tests showed that beta-HCG increased to $32,910 \mathrm{mIU} / \mathrm{mL}$ a week post operation and further increased to $40,614 \mathrm{mIU} / \mathrm{mL}$ on the 8 th day. During these days, patients were regularly reviewed for HCG elevation without special treatment. Several days later, the patient came to our hospital for further treatment, transvaginal ultrasound indicated that mull echo with comparatively prosperous blood flow signals was observed. In the right uterine angle. (Fig. 1) MRI showed there was a visible irregular mixed signal of $30 * 31 * 35 \mathrm{~mm}$ occupying the right uterine angular (Fig. 2a, b). Therefore, she was initially diagnosed with induced incomplete abortion accompanying with angular pregnancy. The patient accepted abortion guided by hysteroscope on April 13, 2018. Intraoperatively, we saw abnormal morphology of uterine cavity with dense adhesions in bilateral uterine wall. Right tubal ostium was invisible while filmy

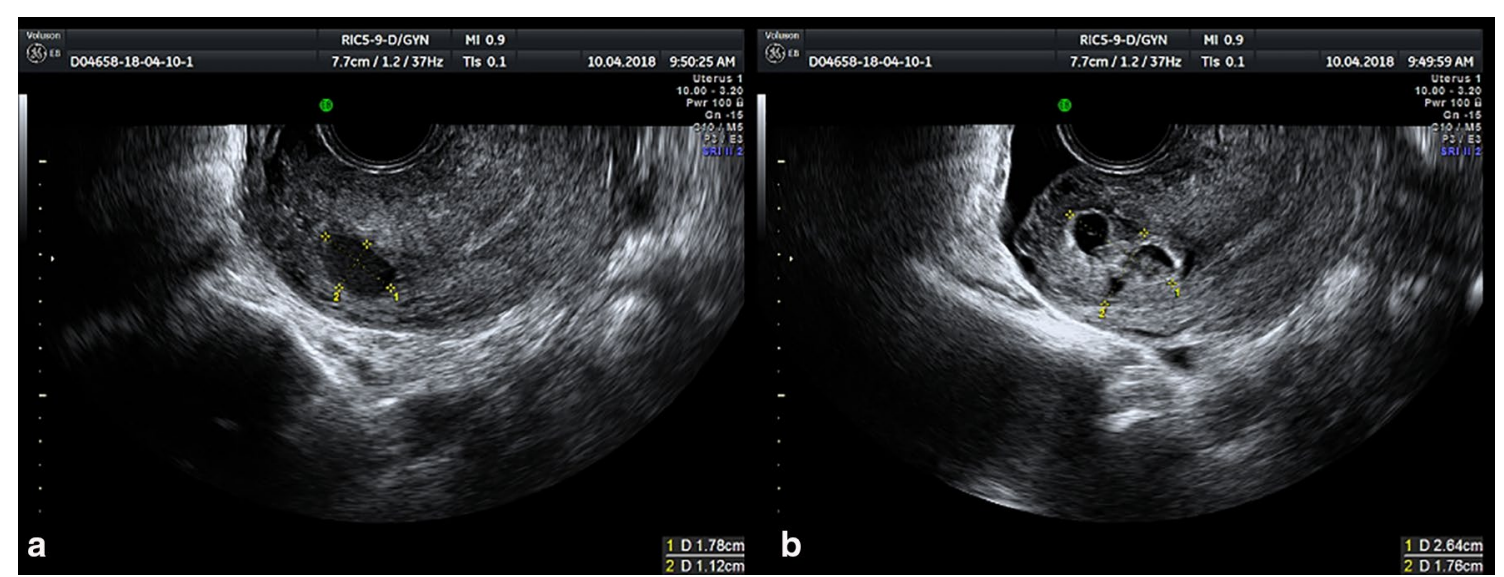

Fig. 1 Transvaginal ultrasound image of case 1. A chaotic echo with a range of $2.64 * 1.76 \mathrm{~cm}$ in a clear boundary, and a liquid dark area with a range of $1.78 * 1.12 \mathrm{~cm}$ were found in right angular of the uterus. Gestation tissue is indicated by measurement of the lesion which looks like yellow dots

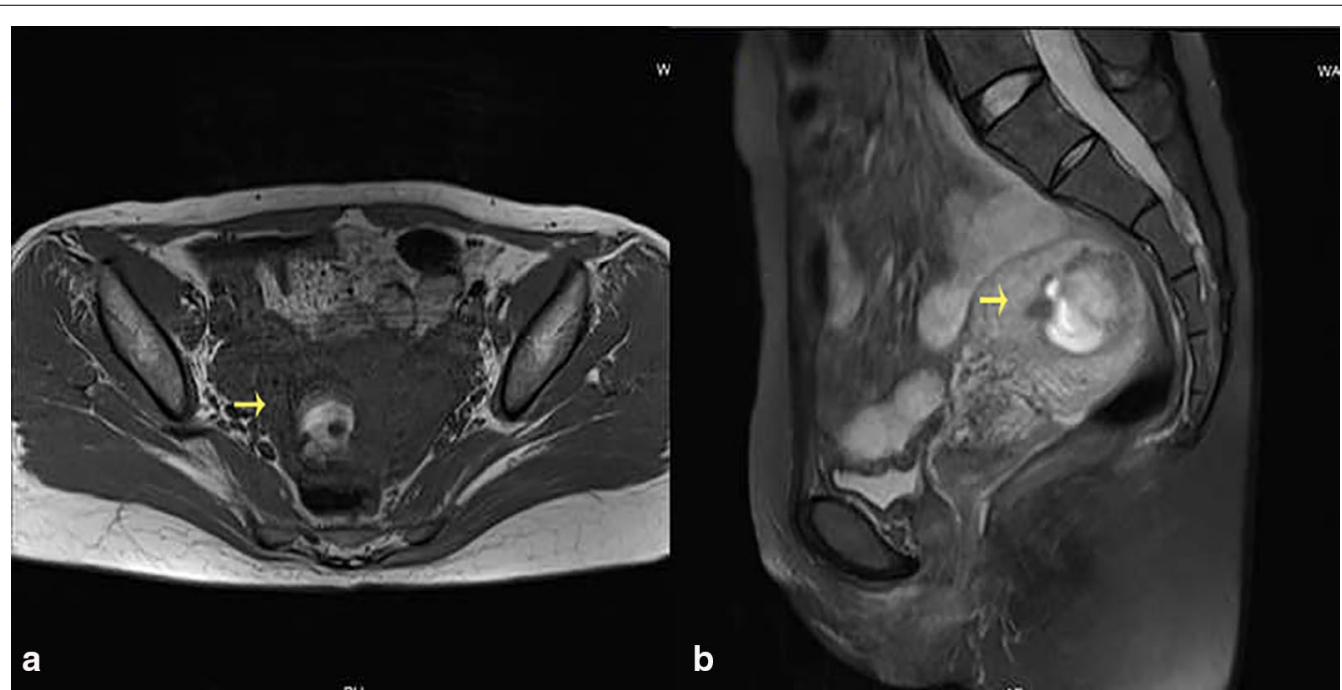

Fig. 2 MRI image of case 1. Postoperative image of artificial abortion, mixed signal mass in the right harem of uterus, suggesting the possibility of residual. The arrow points to the gestation tissue 
adhesions formed in the right cornu, which looked like tubal ostium. When we separated the intrauterine adhesions, the gestational residue was visualized. After suction curettage, some residue was still anchored to the right uterine angle. Finally, the residual pregnancy tissue was excised with hysteroscopic electrode instrumentation, and no residual was found in the uterine cavity. A gross examination fund that intrauterine contents contain chorionic villi. Furthermore, the histological evaluation confirmed the tissue obtained as chorial tissue. Following surgery, beta-HCG was $11,248 \mathrm{mIU} / \mathrm{mL}$ on postoperative day 3. After her 20-day of follow-up, betaHCG reduced to the normal level. There were no procedure-related complications.

\section{Case 2}

A woman aged 43 years, gravida 2 para 1 at 5 weeks, has gone through curettage for incomplete miscarriage in Zhejiang Jiangshan hospital. The 4th day after curettage, she appeared to Jiangshan hospital again for postoperative persistent vaginal bleeding. Endovaginal sonography indicated that abnormal echo in the uterus and trophoblastic disease to be excluded. No special treatment was given at the local hospital and the patient later came to our hospital for further treatment. Endovaginal sonography in our hospital demonstrated similar results as local hospital (Fig. 3). Blood $\beta$-HCG: $4917.2 \mathrm{mIU} / \mathrm{mL}$. We performed hysteroscope for identifying the intrinsic quality of the abnormal echo in the uterus. During surgery, a $3 * 2 \mathrm{~cm}$ villous tissue located in the right angular of the uterus was discovered. And then the villus tissue was carefully excised under hysteroscopy for further examination. Postoperative pathological examination confirmed that villous tissue is decidua. The $\beta$-HCG level in the 1st, 2 nd and 3rd day after surgery is $13727.2 \mathrm{mIU} / \mathrm{mL}, 584.4 \mathrm{mIU} / \mathrm{mL}$ and $346.9 \mathrm{mIU} / \mathrm{mL}$. Post-operative period was uneventful and this patient discharged from hospital 4 days later.

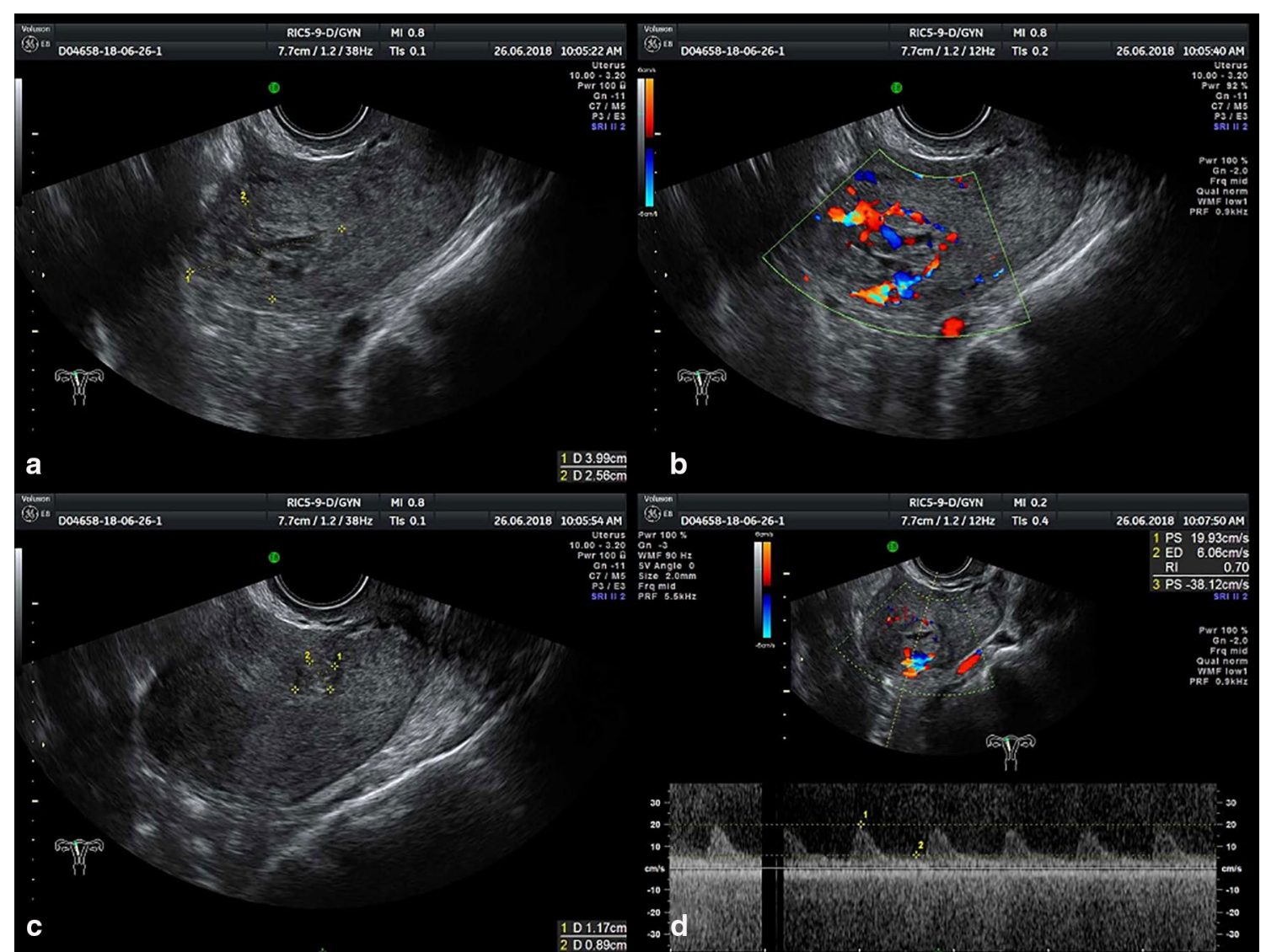

Fig. 3 Endovaginal sonography image of case 2. "Honeycomb-resembling" disordered echoes with unclear border located in the left angular of the uterus measuring in $3.99 * 2.56 \mathrm{~cm}$. In figure $\mathbf{a}$ and $\mathbf{c}$, Gestation tissue is marked by yellow dots which was used to measure gestation tissue. In figure $\mathbf{b}$ and $\mathbf{d}$, yellow measurement line circles gestational sac 


\section{Discussion and conclusions}

Angular pregnancy is characterized as implant medial to the uterotubal junction in lateral angular of uterine. Angular pregnancy is often confused with cornual pregnancy and interstitial pregnancy. These terms are generally used interchangeably in clinical practice and literature and led to lots of confusions in characterizing the natural course of each entity [1]. Cornual pregnancy refers to a kind of ectopic pregnancy that gestational sac implant in the lateral and upper portion of a rudimentary horn or within one horn of a septate or bicornuate uterus. Interstitial pregnancy is a real ectopic pregnancy which is defined as implantation in the intramural portion of Initial part of tuba-uterine which is covered by myometrial layer. It accounts for approximately $2-11 \%$ of tubal ectopic pregnancies and progress asymptomatically beyond the first trimester until uterine rupture followed by hemorrhage at $12-16$ weeks pregnancy [6]. The difference between angular pregnancy and interstitial pregnancy is the position relative to the round ligament as seen at operation. The bulging part of interstitial pregnancy is lateral to the round ligament while the enlarged lateral uterus of an angular pregnancy replaces the round ligament reflection outward and upward. Besides, unlike interstitial pregnancy, angular pregnancy are capable of progress to full term. The rate of angular pregnancy ending in abortion was $38.5 \%$, and the incidence of uterine rupture was $23 \%$. Meanwhile, placental accretism is also a common complication of the third trimester in angular pregnancy $[7,8]$. Therefore, considering that a portion of the complications is potentially deadly, it seems unwise to treat angular pregnancy as a normal pregnancy with a favorable prognosis. We have searched all cases related to angular pregnancy and their prognosis from pubmed (Tables 1, 2).

It is difficult to diagnose angular pregnancy with certainty and hard to judge the exact site of implantation since the gestational sac grows in size. Jansen and Elliott proposed specific criteria for the diagnosis of angular pregnancy in 1981: (1) Clinical presentation with painful

Table 1 All reported cases of angular pregnancy searched from pubmed

\begin{tabular}{|c|c|c|c|c|c|}
\hline Author & Age & Pregnancy history & GAOAP & Side & Treatment \\
\hline Chih-Feng Yen et al. & 38 & G3P1 & $8 W$ & Right & Laparoscopy/hysteroscope \\
\hline Antonio Mollo et al. & 34 & Unknown & $6 W$ & Left & Multiple-dose methotrexate and hysteroscopy surgery \\
\hline Denise E. F. Cordeiro et al. & 28 & G1P1 & Unknown & Right & Emergency laparotomy \\
\hline \multirow[t]{2}{*}{ Katharina Laus et al. } & 27 & G3P1 & $5 \mathrm{~W}$ & Right & $\begin{array}{l}\text { Multi-dose methotrexate/diagnostic Laparoscopy/ } \\
\text { hysteroscope }\end{array}$ \\
\hline & 32 & G1P0 & $7 \mathrm{~W}$ & Right & Laparoscopy/hysteroscope \\
\hline Malihe Hasanzadeh et al. & 34 & G4P1 & $202 / 7 W$ & Left & Emergency laparotomy \\
\hline İbrahim Alanbay et al. & 34 & Unknown & $6 \mathrm{~W}$ & Right & Cesarean section \\
\hline Yusuke Tanaka et al. & 28 & G2P0 & $6 W$ & Right & Unknown \\
\hline Richard B. Mayer et al. & 31 & Unknown & $34 \mathrm{~W}$ & Right & Cesarean section/hysterectomy \\
\hline L. Kambhampati et al. & 41 & G2P1 & $6 \mathrm{~W}$ & Right & Laparoscopy \\
\hline Júlio Augusto Gurgel Alves et al. & 34 & G1P0 & $6 W$ & Right & Cesarean section \\
\hline \multirow[t]{2}{*}{ Ji Young Kwon et al. } & 37 & G3P1 & $5-7 \mathrm{~W}$ & Left & Cesarean section \\
\hline & 22 & G1P0 & $254 / 7 \mathrm{~W}$ & Left & Cesarean section \\
\hline Shashank Shekhar et al. & 26 & G1P0 & $30 \mathrm{~W}$ & Left & Laparotomy \\
\hline Baldawa PS et al. & 32 & G3P1 & $14 \mathrm{~W}$ & Left & $\begin{array}{l}\text { Exploratory laparotomy/subtotal hysterectomy/right } \\
\text { salpingectomy }\end{array}$ \\
\hline \multirow[t]{2}{*}{ Marialuisa Framarino dei Malatesta et al. } & 32 & G1P0 & $7 \mathrm{~W}$ & Left & Transabdominal intralesional injection of methotrexate \\
\hline & 28 & G1P0 & $8 W$ & Right & Transabdominal intralesional injection of methotrexate \\
\hline F.-W. Chang et al. & 30 & $\begin{array}{l}\text { Cesarean/bicor- } \\
\text { nuate uterus } \\
\text { delivery }\end{array}$ & $9 \mathrm{~W}$ & Left & Laparotomy \\
\hline L. R. BARRON et al. & 28 & G3P1 & $14 \mathrm{~W}$ & Left & Laparotomy/hysterectomy/oophorectomy \\
\hline IAN A. MCDOXA et al. & 36 & GOPO & $<8 W$ & Left & Laparotomy \\
\hline LLOYD W. JOHNSTO et al. & 31 & G2P1 & $17 \mathrm{~W}$ & Right & Subtotal hysterectomy \\
\hline T. B. FITZGERA et al. & 29 & G2P1/preterm & $41 \mathrm{~W}$ & Right & Medical induction/caesarean section \\
\hline E P RIGBY & Middle-age & G4P3 & $36 W$ & Left & Laparotomy/hysterectomy \\
\hline JAMES T. Louw et al. & 27 & G3P2 & Unknown & Right & Subtotal hysterectomy \\
\hline
\end{tabular}


Table 2 Chief complaint, prognosis and complications of all reported clinical cases

\begin{tabular}{|c|c|c|c|c|}
\hline Author & PY & Chief complaint & Prognosis & Complications \\
\hline Chih-Feng Yen et al. & 2019 & Severe lower abdominal pain & Abortion & No \\
\hline Antonio Mollo et al. & 2018 & Pelvic pain & Abortion & No \\
\hline Denise E. F. Cordeiro et al. & 2018 & $\begin{array}{l}\text { Mild pelvic pain and moderate } \\
\text { vaginal bleeding }\end{array}$ & Abortion & No \\
\hline \multirow[t]{2}{*}{ Katharina Laus et al. } & \multirow[t]{2}{*}{2018} & Abdominal pain & Abortion & No \\
\hline & & Unknown & Abortion & No \\
\hline Malihe Hasanzadeh et al. & 2017 & Sudden abdominal pain & Abortion & Rupture of lateral wall of the uterus \\
\hline İbrahim Alanbay et al. & 2016 & Unknown & Delivery at $32 \mathrm{~W}$ & Preterm \\
\hline Yusuke Tanaka et al. & 2014 & Unknown & Delivery at $41 \mathrm{~W}$ & No \\
\hline Richard B. Mayer et al. & 2012 & Contractions & Delivery at $34 \mathrm{~W}$ & Preterm/severe bleeding \\
\hline L. Kambhampati et al. & 2012 & Vaginal spotting & Abortion & No \\
\hline Júlio Augusto Gurgel Alves et al. & 2011 & Vaginal bleeding & Delivery at $36 \mathrm{~W}$ & Preterm \\
\hline \multirow[t]{2}{*}{ JiYoung Kwon et al. } & \multirow[t]{2}{*}{2011} & Vaginal spotting & Delivery at 23 4/7 w & Preterm/placental abruption \\
\hline & & Persistent uterine contraction & Delivery at 25 6/7 w & Preterm \\
\hline Shashank Shekhar et al. & 2010 & Preterm & Delivery at 30 W/Hysterotomy & Preterm/retained placenta \\
\hline Baldawa PS et al. & 2008 & Hypovolemic shock & Abortion & Rupture of angular pregnancy \\
\hline \multirow{2}{*}{$\begin{array}{l}\text { Marialuisa Framarino dei Malatesta } \\
\text { et al. }\end{array}$} & \multirow[t]{2}{*}{2007} & Unknown & Abortion & No \\
\hline & & Unknown & Abortion & No \\
\hline F.-W. Chang et al. & 2003 & $\begin{array}{l}\text { Abdominal spasmodic pain and } \\
\text { intermittent vaginal bleeding }\end{array}$ & Abortion & No \\
\hline L. R. BARRON et al. & 1966 & Abdominal pain & Abortion & Ruptures of the uterus \\
\hline IAN A. MCDOXA et al. & 1957 & $\begin{array}{l}\text { Sudden explosive pain with } \\
\text { severe vaginal haemorrhage }\end{array}$ & Abortion & Perforation of uterus \\
\hline LLOYD W. JOHNSTO et al. & 1952 & $\begin{array}{l}\text { Lower abdominal pain and vagi- } \\
\text { nal bleeding }\end{array}$ & Died & $\begin{array}{l}\text { Rupture of the uterine wall/gas- } \\
\text { gangrene infection of the uterus }\end{array}$ \\
\hline T. B. FITZGERA et al. & 1952 & $\begin{array}{l}7 \text { days overdue by her expected } \\
\text { date of Confinement }\end{array}$ & Delivery at full term of gestation & Breech presentation \\
\hline E P RIGBY & 1951 & $\begin{array}{l}\text { Epigastrium and vomiting associ- } \\
\text { ated with pain in the lower } \\
\text { abdomen }\end{array}$ & Fetal death in utero & Ruptures of the uterus \\
\hline JAMES T. Louw et al. & 1947 & $\begin{array}{l}\text { Tonic contraction of the uterus } \\
\text { with constriction ring }\end{array}$ & $\begin{array}{l}\text { Delivery with subtotal hysterec- } \\
\text { tomy }\end{array}$ & No \\
\hline
\end{tabular}

PY publish year

asymmetric. (2) enlargement of the uterus. (3) Direct observation of the lateral expansion of the uterus, with or without rupture, accompanied by lateral displacement of the round ligament reflection. (4) Placenta retention at uterine angle. Similarly, diagnosis of angular pregnancy with ultrasound also confronted with many obstacles as round ligament is not displayed via this technique. When ultrasound found a gestational sac.surrounded primarily by the endometrium with a thick, adjacent endometrium, angular pregnancy can be diagnosed. Intravaginal ultrasound can accurately estimate angular pregnancy, especially in early pregnancy. In 2-D sonogram, an angular pregnancy was highly suspected when the sac is easily visualized with the probe tilted and rotated towards the uterine angle. 3-D sonogram expert in offering scene of uterus that can not be acquired with 2-D sonography. In 3 -D sonogram visualizations of angular pregnancy, the sagittal plane of the uterus clearly shows that the gestational sac is shifted to the upper lateral border of the uterine cavity. The uterine angle at this site is enlarged, and the myometrium is thinner than the contralateral uterine myometrium. Three-dimensional ultrasound and magnetic resonance are of great significance in the diagnosis of angular pregnancy, reduce the possibility of misdiagnosis, assess abnormal placental implantation and predict the risk of uterine rupture [9]. As shown in our cases, these two patients had not been clearly diagnosed with angular pregnancy prior to hysteroscopy, and their surgical indications were incomplete miscarriages.

Hysteroscopy is considered the gold standard procedure for diagnosing and treating uterine cavity pathologies because it provides the opportunity to directly visualize/biopsy and simultaneously treat pathology. Hysteroscopic surgery is an alternative method of uterine 
curettage, which shows the advantages of "visual control", thereby improving complete treatment by limiting the field of surgery, reducing the second procedure rate and intrauterine adhesion. Hysteroscope, directly observe the uterine cavity through the cervix under the endoscope and $\mathrm{CO}_{2}$ gas insufflation. During hysteroscopy, angular pregnancy can be visualized in the upper lateral side of the uterine cavity [10]. Our cases fully demonstrate the significance of hysteroscopy in the diagnosis and treatment of angular pregnancy. Because both of the patients underwent an uneventful postoperative period and discharged from the hospital without any complications.

In conclusion, this is the first case talking about hysteroscopy in diagnosis and treatment of incomplete aborted angular pregnancy, especially in the diagnosis of angular pregnancy. Meanwhile, this case gives us such a revelation: when the patient presents with clinical symptoms of incomplete abortion, we must pay attention to the implantation site of the pregnancy sac, entirely exclude angular pregnancy and other ectopic pregnancy, to avoid misdiagnosis.

\section{Abbreviation}

HCG: Human chorionic gonadotropin.

\section{Acknowledgements}

None.

\section{Authors' contributions}

The author ZJW and FJ studied the concept and designed the report. In this study, ZJW is the main surgeon of this surgery reported in this case. YMC drafted the main part of this manuscript. ZLY participated in a survey of the past history of the two patients in the case, and case presentation part was written by ZLY. ZJW read and approved the final manuscript. All authors read and approved the final manuscript.

\section{Funding}

This work was supported by the Natural Science Foundation of Zhejiang Province (LY2OH160028 to Jianwei Zhou) and Youth Program of National Natural Science Foundation of China (No.81902633 to Jing Fei). The Article Processing Charge for open access publication was granted by Natural Science Foundation of Zhejiang Province (LY20H160028) and Youth Program of National Natural Science Foundation of China (No.81902633). Besides the payment of the APC, there has been no additional funding for the design of the study, or the collection, analysis and interpretation of data and writing of the manuscript. The author ZJW and FJ studied the concept and designed the report. ZJW is the main surgeon of this surgery reported in this case.

\section{Availability of data and materials}

The datasets supporting the conclusions of this article are included within the article.

\section{Ethics approval and consent to participate}

This study was approved by the second affiliated hospital of Zhejiang University School of Medicine Ethics Committee. In the process of research, we strictly followed the relevant management regulations of medical ethics and carried out relevant work under the supervision.

\section{Consent for publication}

The written consent for publication of the manuscript, including personal and clinical details, and any identifying images, was obtained from BOTH featured patients.

\section{Competing interests}

YMC, ZLY, and ZJW declare that they have no competing interests about this case and all authors have read and approved the manuscript.

Received: 1 September 2020 Accepted: 27 January 2021

Published online: 09 February 2021

\section{References}

1. Jansen RP, Elliott PM. Angular intrauterine pregnancy. Obstet Gynecol. 1981;58:167-75.

2. Triolo O, Mancuso A, De Vivo A, et al. Term angular pregnancy with placenta accreta. A case report. Clin Exp Obstet Gynecol. 2004;31 (2):147-8.

3. Deckers EA, Stamm CA, Naake VL, Dunn T, et al. Hysterotomy for retained placenta in a term angular pregnancy. A case report. J Reprod Med. 2000:45(2):153-5.

4. Stiller RJ, de Regt RH. Prenatal diagnosis of angular pregnancy. J Clin Ultrasound. 1991;19(6):374-6.

5. Smorgick N, Barel O, Fuchs N, et al. Hysteroscopic management of retained products of conception: meta-analysis and literature review. Eur J Obstet Gynecol Reprod Biol. 2014;173:19-22.

6. Arleo EK, DeFilippis EM. Cornual, interstitial, and angular pregnancies: clarifying the terms and a review of the literature. Clin Imaging. 2014;38(6):763-70.

7. Hasanzadeh M, Dadgar S, Arian Y, et al. Angular ectopic pregnancy presenting as rupture of lateral wall of the uterus: late presentation in gestation week 20. Iran J Med Sci. 2017:42(3):314-7.

8. Baldawa PS, Chaudhari HK. Angular ectopic pregnancy presenting as rupture of lateral wall of the uterus. J Hum Reprod Sci. 2008;1 (1):33-4

9. Tanaka Y, Mimura K, Kanagawa T, et al. Three-dimensional sonography in the differential diagnosis of interstitial, angular, and intrauterine pregnancies in a septate uterus. J Ultrasound Med. 2014;33(11):2031-5.

10. Yen $\mathrm{C}-\mathrm{F}$, Chou H-H, Hsien-Ming Wu, et al. Effectiveness and appropriateness in the application of office hysteroscopy. J Formos Med Assoc. 2019;118(11):1480-7.

\section{Publisher's Note}

Springer Nature remains neutral with regard to jurisdictional claims in published maps and institutional affiliations.

Ready to submit your research? Choose BMC and benefit from:

- fast, convenient online submission

- thorough peer review by experienced researchers in your field

- rapid publication on acceptance

- support for research data, including large and complex data types

- gold Open Access which fosters wider collaboration and increased citations

- maximum visibility for your research: over 100M website views per year

At BMC, research is always in progress.

Learn more biomedcentral.com/submissions 